\title{
Growth and Yield of Finger Millet (Eleusine coracana L. Gaertn.) as Influenced by Intercropping with Pulses
}

\author{
Dhimmagudi Ramamohan Reddy ${ }^{1 *}$, P. Shalini Pillai ${ }^{1}$, Jacob John², \\ A. Sajeena ${ }^{2}$ and J. C. Aswathy ${ }^{1}$ \\ ${ }^{1}$ Department of Agronomy, Kerala Agricultural University, College of Agriculture, \\ Vellayani, Thiruvananthapuram, Kerala, India \\ ${ }^{2}$ Kerala Agricultural University, Integrated Farming System Research Station, \\ Karamana, Thiruvananthapuram, Kerala, India \\ *Corresponding author
}

\section{A B S T R A C T}

\section{Keywords}

Finger millet Eleusine coracana, Arbuscular mycorrhizal fungi

\section{Article Info}

Accepted:

20 July 2020

Available Online:

10 August 2020
A study was conducted at Integrated Farming System Research Station, Karamana, Thiruvananthapuram, Kerala, to assess the effect of intercropping in finger millet and to assess the effect of AMF on the growth and yield of finger millet. The field experiment was laid out in randomized block design with 11 treatments replicated thrice. The treatments comprised finger millet (with and without AMF) intercropped with pulses, viz., green gram, black gram and cowpea along with the sole crop of all the above crops. The results elicited that both AMF and intercropping had significant effect on the growth and yield of finger millet. The sole crop of finger millet with AMF was found to show superior growth and yield attributes of finger millet. Among the intercropping systems, finger millet (with AMF) + cowpea was found to excel in the growth and yield.

\section{Introduction}

Millets are regarded as one of the ancient foods known to mankind. The hardy nature of millets has gained them the recognition as the staple food of people living in the drier parts of the world. Millets are also known as 'famine reserves' due to their prolonged shelf life of more than two years without deterioration (Sahu and Sharma, 2013). Further, millets are nutritionally comparable or even superior to rice and wheat with respect to protein, energy, vitamins, and minerals (Sehgal and Kawatra, 2003). Thus, millets which were once christened as poor man's food is acquiring acceptance in the food basket of the rich as the keystone towards a healthy and sustainable food revolution. Finger millet (Eleusine coracana (L.) Gaertn) is cultivated in the tropical and subtropical regions, has been reported to thrive on hardly 28 per cent of the water requirement of rice (Triveni et al., 2017). India, finger millet occupied an area of 1.19 million hectares accounting for a production of 1.98 million tonnes and an average 
productivity of $1661 \mathrm{~kg} \mathrm{ha}^{-1}$ (Sakamma et al., 2018). As for Kerala, finger millet was reported in an area of 33 ha covering the districts of Palakkad and Idukki with a production of $42 \mathrm{t}$ (FIB, 2019).

The ever-shrinking per capita land availability warrants both temporal and spatial intensification of agricultural systems (Kiwia et al., 2019). Crop diversification through intercropping has been acknowledged as a principal pillar for ensuring sustainable development. Crops which vary in their growth habits are grown together so that they complement one another resulting in higher resource use efficiency. Legumes assume paramount importance in intercropping systems involving cereals / millets because of their ability to fix and transfer nitrogen. Sole cropping of millets like finger millet is usually not appreciably remunerative and it fails to satisfy the diverse consumer demand. The initial slow growth phase of finger millet can be utilized for raising short duration pulses. Moreover, intercropping with fast growing pulses will also help in reducing the weed problems. Combining intercropping with biofertilization has been observed to enhance crop productivity and soil fertility. Linking cereal - legume intercropping through common mycorrhizal network improves the productivity of crops (Hauggaard-Nielsen and Jensen, 2005). Hence, the study entitled was undertaken to assess the productivity of intercropping finger millet with pulses, to study the effect of AMF on the performance of finger millet under intercropping and to work out the land equivalent ratio (LER).

\section{Materials and Methods}

A field experiment was conducted at Integrated Farming System Research Station, Karamana, Thiruvananthapuram, Kerala, during the summer 2019 - 2020 where finger millet variety PPR 2700, was intercropped with pulses, viz., green gram (CO 8), black gram (DU 1) and cowpea (Kanakamony), in the ratio $4: 1$. Finger millet was raised with and without arbuscular mycorrhizal fungi (AMF), which was obtained from the Department of Agricultural Microbiology, College of Agriculture, Vellayani. The experiment was laid out in randomized block design with 11 treatments replicated three times. Arbuscular mycorrhizal fungi (AMF) were applied to finger millet at the time of sowing. The treatments comprised of finger millet (with or without) intercropped with pulses, viz., green gram, black gram and cowpea and the sole crop of all the four mentioned crops. The soil of the experimental site was sandy clay loam in texture, strongly acidic in reaction, high in organic carbon, low in available nitrogen and medium in available phosphorus and potassium status. The data generated were statistically analysed using analysis of variance technique (ANOVA), as applied to randomized block design (Gomez and Gomez, 2010).

\section{Results and Discussion}

\section{Growth and Growth Attributes}

The results of the study revealed that intercropping had significant effect on the growth and growth attributes of finger millet. The effect of intercropping on plant height and LAI of finger millet exhibited significance only at $30 \mathrm{DAS}$. The tiller count was observed to vary significantly with intercropping at 30 and 60 DAS whereas dry matter production varied significantly at 30 and 60 DAS as well as at harvest (Table 1 and 2). Among the intercropping systems, $\mathrm{T}_{8}$ (finger millet with AMF + cowpea) registered the highest dry matter production. The higher LAI, tiller count, crop growth rate and relative growth rate supported by this treatment might have contributed to the higher dry matter 
production. Dry matter production and light interception are directly related and light interception is mainly dependent on the LAI (Ewert, 2004; Portes and de Melo, 2014).

Crop growth rate of finger millet was significantly higher in sole crop of finger millet with AMF $\left(\mathrm{T}_{2}\right)$, both at 30 to $60 \mathrm{DAS}$ (6.373 $\mathrm{g} \mathrm{m}^{-2}$ day) and 60 DAS to harvest (5.830 $\mathrm{g} \mathrm{m}^{-2}$ day). Similar trend was observed with relative growth rate also (Table 3 ). Between the sole crops of finger millet, without and with AMF ( $\mathrm{T}_{1}$ and $\mathrm{T}_{2}$ ), growth attributes such as plant height, tillers per plant, LAI, total dry matter production, crop growth rate and relative growth rate were observed to be significantly higher with application of AMF. The total dry matter produced by finger millet at harvest was 16.9 per cent higher with AMF. Irrespective of the pulse intercropped, AMF improved the growth attributes of finger millet. Arbuscular mycorrhizal fungi have been reported to possess consistent impact on stomatal conductance, transpiration, $\mathrm{CO}_{2}$ exchange, photosynthesis and chlorophyll content (Panwar, 1991) and consequently plant growth. Inoculating AMF has been observed to result in significant increase in growth rate and dry matter production of crops (Mudalagiriyappan et al., 1997). Increases in crop growth rate and relative growth rate are mainly mediated by an increase in leaf area index and consequent improvement in radiation use efficiency. Similar results have been reported by Chavan et al., (2019).

\section{Yield of Finger Millet}

Grain yield and straw yield were superior for sole crop of finger millet treated with AMF $\left(\mathrm{T}_{2}\right)$ compared to that without AMF $\left(\mathrm{T}_{1}\right)$ (Fig. 1). Inoculation with $\mathrm{AMF}$ was observed to improve the yield of finger millet intercropped with green gram, black gram and cowpea. Compared to sole crop, yield reduction of finger millet (without AMF) was to the tune of 20.01, 24.05 and 16.38 percent respectively with green gram, black gram and cowpea. However, the same with AMF was only 10.42, 11.36 and 7.01 per cent. This shows the effect of AMF in enhancing competitive ability of finger millet under intercropped situation.

Table.1 Effect of intercropping on plant height and tillers per plant of finger millet

\begin{tabular}{|l|c|c|c|c|c|c|}
\hline \multirow{2}{*}{ Treatment } & \multicolumn{3}{|c|}{ Plant height $(\mathbf{c m})$} & \multicolumn{3}{c|}{ Tillers per plant (nos) } \\
\cline { 2 - 7 } & 30 & 60 & At & 30 & 60 & \multicolumn{1}{|c|}{ At } \\
harvest
\end{tabular}


Table.2 Effect of intercropping on leaf area index and total dry matter production of finger millet

\begin{tabular}{|c|c|c|c|c|c|c|}
\hline \multirow[t]{2}{*}{ Treatment } & \multicolumn{3}{|c|}{ Leaf area index } & \multicolumn{3}{|c|}{ Total dry matter production $\left(\mathrm{kg} \mathrm{ha}^{-1}\right)$} \\
\hline & 30 DAS & 60 DAS & At harvest & 30 DAS & 60 DAS & At harvest \\
\hline $\begin{array}{l}T_{1} \text { : Finger millet as sole crop (without } \\
\text { AMF) }\end{array}$ & 0.75 & 2.47 & 3.18 & 1005 & 3355 & 4942 \\
\hline $\begin{array}{l}T_{2} \text { : Finger millet as sole crop (with } \\
\text { AMF) }\end{array}$ & 0.80 & 3.01 & 3.87 & 1174 & 3921 & 5775 \\
\hline $\begin{array}{l}T_{3} \text { : Finger millet (without AMF) + green } \\
\text { gram }\end{array}$ & 0.62 & 2.11 & 3.08 & 810 & 2705 & 3984 \\
\hline $\begin{array}{l}\left.\mathbf{T}_{4}: \text { Finger millet (with } \mathrm{AMF}\right)+ \text { green } \\
\text { gram }\end{array}$ & 0.68 & 2.38 & 3.18 & 908 & 3034 & 4469 \\
\hline $\begin{array}{l}\text { T}_{5} \text { : Finger millet (without AMF) + black } \\
\text { gram }\end{array}$ & 0.60 & 2.23 & 2.89 & 770 & 2572 & 3788 \\
\hline $\begin{array}{l}\mathbf{T}_{6} \text { : Finger millet (with AMF) + black } \\
\text { gram }\end{array}$ & 0.64 & 2.32 & 3.25 & 898 & 2999 & 4417 \\
\hline $\begin{array}{l}\mathbf{T}_{7}: \text { Finger millet (without AMF) + } \\
\text { cowpea }\end{array}$ & 0.65 & 2.50 & 3.09 & 847 & 2828 & 4165 \\
\hline$T_{8}:$ Finger millet (with AMF) + cowpea & 0.57 & 2.30 & 2.93 & 942 & 3148 & 4635 \\
\hline$T_{9}:$ Green gram as sole crop & - & - & - & - & - & - \\
\hline $\mathrm{T}_{10}$ : Black gram as sole crop & - & - & - & - & - & - \\
\hline$T_{11}:$ Cowpea as sole crop & - & - & - & - & - & - \\
\hline $\operatorname{SE~} \mathrm{m}( \pm)$ & 0.041 & 0.25 & 0.24 & 15 & 49 & 72 \\
\hline CD (0.05) & 0.126 & NS & NS & 45.2 & 150.5 & 221.4 \\
\hline
\end{tabular}

NS - Not significant

Table.3 Effect of intercropping on crop growth rate and relative growth rate of finger millet

\begin{tabular}{|c|c|c|c|c|}
\hline \multirow[t]{2}{*}{ Treatment } & \multicolumn{2}{|c|}{$\begin{array}{l}\text { Crop growth rate } \\
\qquad\left(\mathrm{g} \mathrm{m}^{-2} \text { day }^{-1}\right)\end{array}$} & \multicolumn{2}{|c|}{$\begin{array}{l}\text { Relative growth } \\
\text { rate }\left(\mathrm{g} \mathrm{g} \mathrm{g}^{-1} \text { day }^{-1}\right)\end{array}$} \\
\hline & $\begin{array}{c}30-60 \\
\text { DAS }\end{array}$ & $\begin{array}{l}60 \text { DAS } \\
\text { to harvest }\end{array}$ & $\begin{array}{c}30-60 \\
\text { DAS }\end{array}$ & $\begin{array}{l}60 \text { DAS } \\
\text { to harvest }\end{array}$ \\
\hline$T_{1}$ : Finger millet as sole crop (without AMF) & 5.337 & 5.257 & 0.307 & 0.182 \\
\hline$T_{2}:$ Finger millet as sole crop (with AMF) & 6.373 & 5.830 & 0.414 & 0.275 \\
\hline $\mathbf{T}_{3}$ : Finger millet (without AMF) + green gram & 4.500 & 4.693 & 0.325 & 0.174 \\
\hline $\mathbf{T}_{4}:$ Finger millet (with AMF) + green gram & 4.797 & 5.383 & 0.347 & 0.183 \\
\hline $\mathrm{T}_{5}$ : Finger millet (without AMF) + black gram & 4.690 & 4.543 & 0.313 & 0.161 \\
\hline $\mathbf{T}_{6}:$ Finger millet (with AMF) + black gram & 4.993 & 4.197 & 0.350 & 0.175 \\
\hline $\mathbf{T}_{7}$ : Finger millet (without AMF) + cowpea & 4.733 & 4.340 & 0.337 & 0.197 \\
\hline $\mathbf{T}_{8}:$ Finger millet (with AMF) + cowpea & 4.807 & 4.530 & 0.377 & 0.246 \\
\hline $\mathbf{T}_{9}:$ Green gram as sole crop & - & - & - & - \\
\hline$T_{10}$ : Black gram as sole crop & - & - & - & - \\
\hline$T_{11}:$ Cowpea as sole crop & - & - & - & - \\
\hline $\operatorname{SE~m~}( \pm)$ & 1.352 & 0.328 & 0.005 & 0.004 \\
\hline CD (0.05) & 1.0771 & 1.0030 & 0.0162 & 0.0151 \\
\hline
\end{tabular}


Fig.1 Effect of intercropping on the grain yield and straw yield of finger millet, $\mathrm{tha}^{-1}$

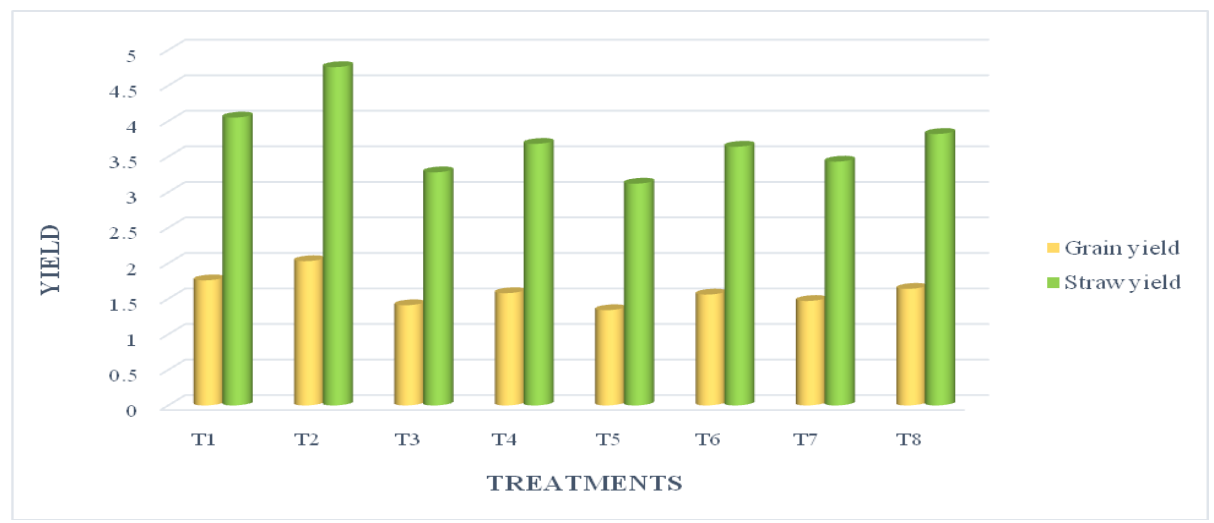

Fig.2 Effect of intercropping on land equivalent ratio

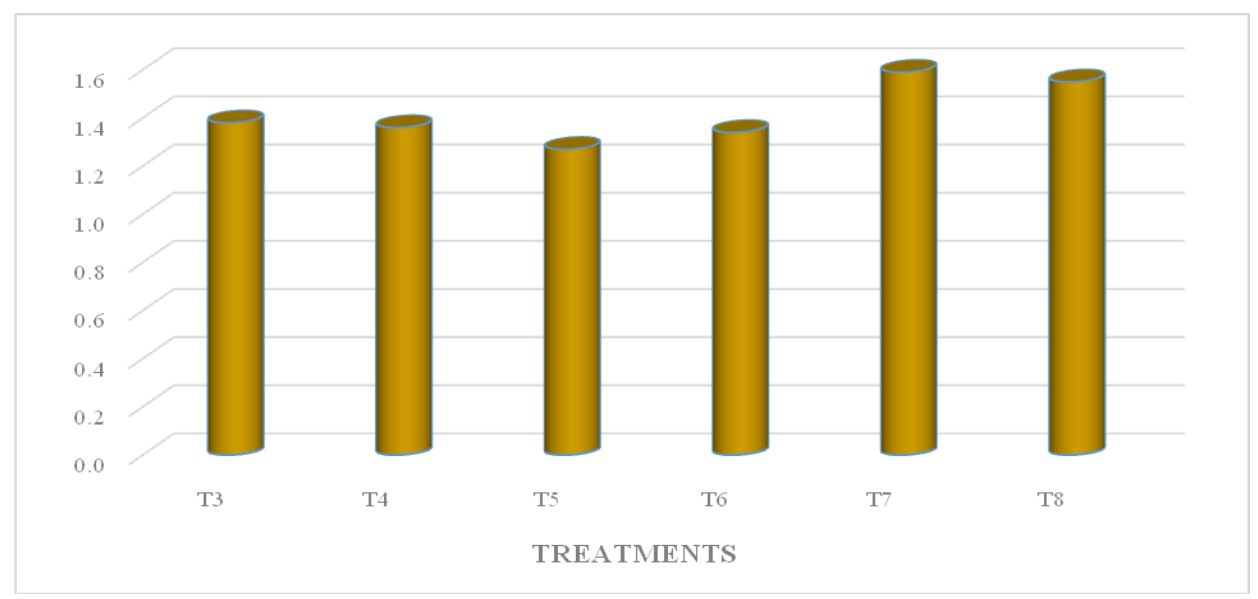

The increase in productivity, in response to AMF has been mainly attributed to the ability of AMF in enhancing the uptake of relatively immobile nutrients clubbed together with the rapid translocation of the mobile nutrients (Tobar et al., 1994; Liu et al., 2000).

Among the intercropping systems, $\mathrm{T}_{8}$ (finger millet with $\mathrm{AMF}+$ cowpea) recorded superiority in yield attributes and yield. This might be due to a better complementarity between finger millet and cowpea in utilizing the basic resources like water, nutrients and sunlight, as suggested by Kumar and Ray (2020). The positive impact of AMF in improving the yield attributes of finger millet was observed across all the intercropping systems, irrespective of the pulse. This could be attributed to the role of AMF in promoting inter-specific root interactions between finger millet and pulses, effecting nutrient mobilization in the rhizosphere (Wasaki et al., 2003), resulting in better growth and productivity of finger millet.

\section{Land Equivalent Ratio}

Land equivalent ratio (LER) is the relative area required under sole cropping to produce the yield realized under intercropping. LER values greater than unity denotes yield advantage. Intercropping finger millet (without AMF) + cowpea $\left(\mathrm{T}_{7}\right)$ recorded the highest LER (1.59), followed by $\mathrm{T}_{8}$ (finger millet with AMF + cowpea) (Fig. 2). Intercropping finger millet with green gram 
recorded an LER of 1.38 and 1.37 respectively for finger millet without $\mathrm{AMF}$ $\left(\mathrm{T}_{3}\right)$ and finger millet with AMF $\left(\mathrm{T}_{4}\right)$. Comparatively, LER was lower for intercropping black gram in finger millet.

The general observation was that LER which is based on the actual crop yields were greater than unity, signifying that all three intercrops, viz., green gram, black gram and cowpea were capable of utilizing the available resources efficiently than expected, compared to their respective sole crop yields. According to Vandermeer (1989), intercrops that result in LER values greater than unity are considered to over yield, gaining their advantage through the 'competitive production principle' and/or the 'facilitative production principle'. The higher LER in intercropping than sole cropping could be attributed to the better utilization of both natural and supplemented resources.

In conclusion from the above study it was evident that the application of AMF on finger millet had a positive effect on the growth and yield of finger millet. Further, the intercropping in finger millet with pulses viz. green gram, black gram and cowpea which was indicated by the LER greater than one. Among the intercropping systems, intercropping finger millet with cowpea along with AMF application was found to be remunerative.

\section{References}

Chavan, I.B., Jagtap, D.N., and Mahadkar, U.V. 2019. Yield and quality of finger millet (Eleusine coracana L. Gaertn.) influenced due to different establishment techniques, levels and times of nitrogen. Adv. Agric. Res. Technol. J. 3(2): 191-200.

Ewert, F. 2004. Modelling plant responses to elevated $\mathrm{CO}_{2}$; how important is the leaf area index? Ann. Bot. 93(6): 619-627.

FIB [Farm Information Bureau]. 2019. Farm Guide 2019. Agriculture Development and Farmers' Welfare Department, Government of Kerala, Kowdiar, Thiruvananthapuram, 294p.

Hauggaard-Nielsen, H. and Jensen, E. S. 2005. Facilitative root interactions in intercrops. Plant Soil 274: 237-250.

Kiwia, A., Kimani, D., Harawa, R., Jama, B., and Sileshi, G.W. 2019. Sustainable intensification with cereal-legume intercropping in eastern and southern Africa. Sustainability 11: 1-18.

Kumar, B. and Ray, P.K. 2020. Finger millet intercropping with legumes step towards increasing farmer's income. Int $J$. Chem. Studies 8(3): 1038-1040.

Liu A., Hamel C., Hamilton R. I., and Smith D. L. 2000. Mycorrhizae formation and nutrient uptake of new corn (Zea mays L.) hybrids with extreme canopy and leaf architecture as influenced by soil $\mathrm{N}$ and P levels. Plant Soil 221: 157-166.

Mudalagiriyappan, C.A., Agasimani, K.K., Veeranna, S., and Najappa, H.V. 1997. Nutrient recovery and balance sheet of nitrogen and phosphorus as influenced by sources of phosphate solubilizers and phosphate on groundnut. Mysore. J. Bot. 32: 143-148.

Panwar, J.D.S. 1991. Effect of Azospirillum brasilense and arbuscular mycorrhizal fungi on photosynthesis, nitrogen metabolism and grain yield in wheat. Indian.J.Pl.Physiol. 34(4):357-361.

Portes, T.D. and de Melo, H.C. 2014. Light interception, leaf area and biomass production as a function of density of maize plants analysed using mathematical models. Acta Sci. Agron. 36(4): 346-367.

Sahu, R.K. and Sharma, M.L. 2013. Medical and other use of small millets by the tribal farmers of the Bastar plateau Zone of Chhattisgarh. Ambio. 8(4): 596- 
599.

Sakamma, S., Umesh, K.B., Girish, M.R., Ravi, S.C., Sathishkumar, M., Bellundagi, V. 2018. Finger Millet (Eleusine coracana L. Gaertn.) production system: status, potential, constraints and implications for improving small farmers' welfare. $J$. Agric. Sci. 10(1): 163-179.

Sehgal, A. and Kawatra, A. 2013. Processing and utilization of pearl millet for nutritional security. In: Proceedings of National Seminar on Recent Trends in Millet Processing and Utilization, 14-16 January, 2003, Haryana Agricultural University, Hissar, India, pp. 1-6.

Tobar, R.M., Azcón, R., and Barea, J.M. 1994. Improved nitrogen uptake and transport from ${ }^{15} \mathrm{~N}$ - labelled nitrate

by external hyphae of arbuscular mycorrhiza under water- stressed conditions. New Phytologist 126: 119122.

Triveni, U., Rani, Y.S., Patro, T.S.S.K., Anuradha, N., and Divya, M. 2017. Evaluation of different finger millet based intercropping systems in the northern coastal zone of Andhra Pradesh. Int. J. Chem. Studies 5(5): 828831.

Vandermeer, J.H. 1989. The Ecology of Intercropping. Cambridge University Press, Cambridge, Great Britain, 237 p.

Wasaki, J., Yamamura, T., Shinano, T., and Osaki, M. 2003. Secreted acid phosphatase is expressed in cluster lupin in response to phosphorus deficiency Plant Soil 248: 129-136.

\section{How to cite this article:}

Dhimmagudi Ramamohan Reddy, P. Shalini Pillai, Jacob John, A. Sajeena and Aswathy, J. C. 2020. Growth and Yield of Finger Millet (Eleusine coracana L. Gaertn.) as Influenced by Intercropping with Pulses. Int.J.Curr.Microbiol.App.Sci. 9(08): 2297-2303. doi: https://doi.org/10.20546/ijcmas.2020.908.263 